$\frac{\pi T}{1620} 19.3: 2097$

\title{
NURE Geochemical and Geophysical Surveys- Defining Prospective Terranes for United States Placer Exploration
}

\section{7}

\section{U.S. GEOLOGICAL SURVEY BULLETIN 2097}





\section{NURE Geochemical and Geophysical Surveys- Defining Prospective Terranes for United States Placer Exploration}

By Andrew E. Grosz and Paul G. Schruben

\section{U.S. GEOLOGICAL SURVEY BULLETIN 2097}

A technique for using the National Uranium Resource Evaluation geochemical and geophysical data for titanium, zirconium, hafnium, and rare-earth-bearing placer deposit exploration in the conterminous

United States and Alaska

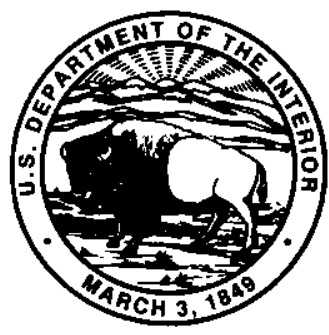




\title{
U.S. DEPARTMENT OF THE INTERIOR BRUCE BABBITT, Secretary
}

\author{
U.S. GEOLOGICAL SURVEY \\ GORDON P. EATON, Director
}

For sale by U.S. Geological Survey, Information Services

Box 25286, Federal Center, Denver, CO 80225

Any use of trade, product, or firm names in this publication is for descriptive purposes only and does not imply endorsement by the U.S. Government.

Published in the Eastern Region, Reston, Va. Manuscript approved for publication May 6, 1994.

\section{Library of Congress Cataloging in Publication Data}

Grosz, A.E. (Andrew E.)

NURE geochemical and geophysical surveys-defining prospective terranes for placer exploration in the United States / by Andrew E. Grosz and Paul G. Schruben.

p. $\mathrm{cm}$. - (U.S. Geological Survey bulletin ; 2097)

"A technique for using the National Uranium Resource Evaluation geochemical and geophysical data for titanium, zirconium, hafnium, and rare-earth-bearing placer deposit exploration in the conterminous United States and Alaska."

Includes bibliographical references.

1. Heavy minerals-Prospecting--United States. 2. Geochemical prospecting-United States. 3. Prospecting-United States-Geophysical methods. 4. Placer deposits-United States. I. Schruben, Paul G. II. Title. III. Series.

QE75.B9 no. 2097

[TN271.H43]

$557.3 \mathrm{~s}-\mathrm{dc} 20$

[553.4] 


\section{CONTENTS}

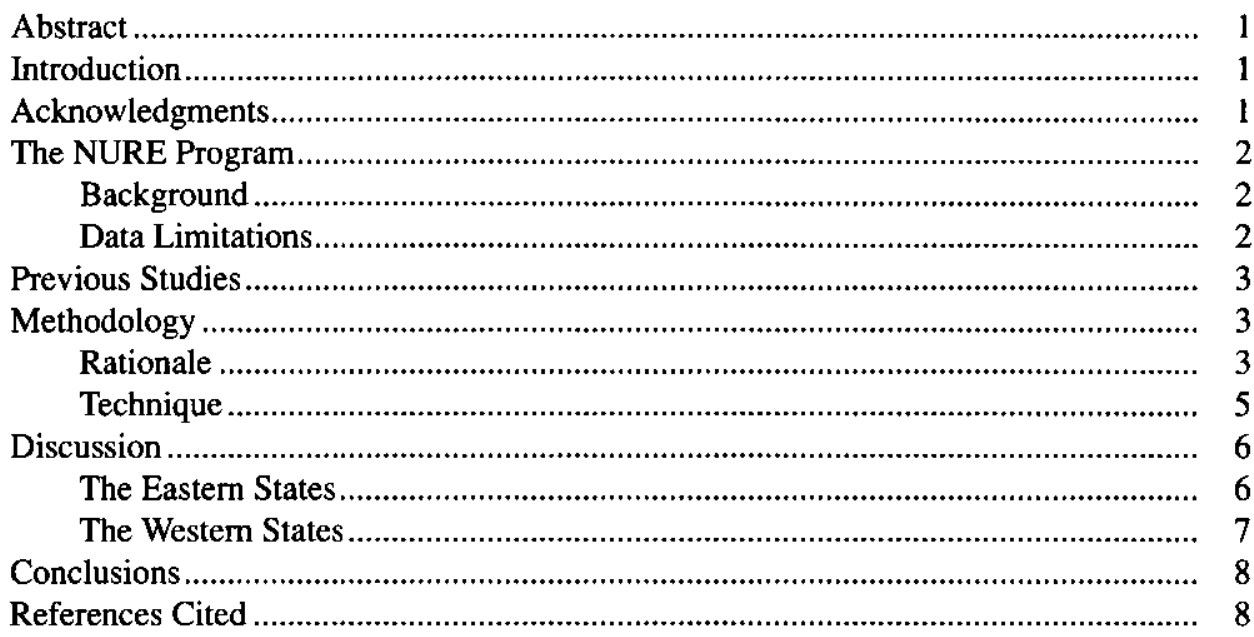

\section{PLATES}

[Plates are in pocket]

1. Map showing the locations of anomalous titanium, hafnium, and rare earth elements in Virginia, North Carolina, South Carolina, and Georgia.

2. Map showing the locations of anomalous titanium, zirconium or hafnium, and rare earth elements in Washington, Oregon, Idaho, Montana, and Wyoming.

\section{FIGURES}

1-6. Graphs showing the relation between-

1. Cerium and lanthanum in samples having greater than 0.05 percent REE from the eastern States

2. Cerium and thorium in samples having greater than 0.05 percent REE from the eastern States

3. Thorium and uranium in samples having greater than 0.05 percent REE from the eastern States

4. Cerium and lanthanum in samples having greater than 0.0096 percent REE from the western States.

5. Cerium and thorium in samples having greater than 0.0096 percent REE from the western States

6. Zirconium and hafnium in 661 samples from the western States.

\section{METRIC CONVERSION FACTORS}

\begin{tabular}{rll}
\hline Multiply & \multicolumn{1}{c}{ By } & To obtain \\
\hline & Length & \\
micrometer $(\mu \mathrm{m})$ & 0.00003937 & inch \\
meter $(\mathrm{m})$ & 3.281 & foot \\
kilometer $(\mathrm{km})$ & 0.6214 & mile \\
& Mass & \\
kilogram $(\mathrm{kg})$ & 2.205 & pound avoirdupois \\
megagram $(\mathrm{Mg})$ & 1.102 & ton \\
\hline
\end{tabular}





\title{
NURE Geochemical and Geophysical Surveys- Defining Prospective Terranes for United States Placer Exploration
}

\author{
By Andrew E. Grosz and Paul G. Schruben
}

\begin{abstract}
Titanium ( $\mathrm{Ti})$, zirconium $(\mathrm{Zr})$, hafnium $(\mathrm{Hf})$, and rareearth element (REE) data from the Hydrogeochemical Stream Sediment Reconnaissance data base of the National Uranium Resource Evaluation (NURE) program are diagnostic of, and may predict the presence of, commercially important heavy minerals. Examples from the eastern and westem United States show that concentrations of these elements in sediment samples can indicate the presence of commercially important heavy minerals such as ilmenite, rutile, zircon, and monazite. Ilmenite and rutile are the most commonly occurring Ti-bearing minerals in sediments. The presence of $\mathrm{Hf}$ (or $\mathrm{Zr}$ ) usually indicates the presence of zircon.

Plots of anomalous outliers of these elements outline known placer deposits of heavy minerals in (1) the North Carolina-South Carolina State-line region along the Fall Zone, (2) coastal South Carolina, (3) at the base of the Fall Zone near the South Carolina-Georgia State line, (4) Upper Cretaceous black sandstones and fossil placers in younger sediments in Montana, and (5) in known placer districts in Idaho and Montana. Volcanic, plutonic, and metamorphic rocks in the eastem and the westem States are the source of the minerals found in these regions.

The data outline a large area in the Coastal Plain province in Virginia and North Carolina, particularly over fossil shoreline deposits, and several areally extensive regions in Idaho and Oregon for Ti-Hf-REE-bearing placer exploration. Evidence for other potential Ti-Hf-REE placer deposits is given for unconsolidated Coastal Plain sediments along the Fall Zone from Virginia to Georgia and for large segments of Montana in areas underlain by stratified marine and continental deposits. Fall Zone sediments in North Carolina, South Carolina, and Georgia make up an REE-Hf province, and the Idaho batholith makes up an REE province. A good correlation between the abundances of cerium (Ce) and lanthanum ( $\mathrm{La}), \mathrm{Ce}$ and thorium (Th), and Th and uranium (U) in the sediment samples shows that NURE airborne spectral gamma-ray radiation survey data can be used to outline large geographic provinces favorable for monazite-bearing placer exploration.
\end{abstract}

Other parts of the conterminous United States, particularly in the largely unexplored Central Plains, appear suitable for similar study. The potential for Ti-Hf-REE-Th-Ubearing deposits of heavy-mineral suites in the United States may be much greater than previously recognized.

\section{INTRODUCTION}

Deposits of placer heavy minerals in unconsolidated sediments, both of the fluvial and beach-complex type, furmish most of the world's ilmenite, rutile, zircon, and monazite. Other heavy minerals such as staurolite and tourmaline, which are used as abrasives, are common byproducts of placer mining operations.

Exploration for placers traditionally has relied upon geomorphologic and geologic methods. Exploration commonly consists of preliminary field sampling of surficial sediments followed by drilling of geomorphologically defined targets. Most commonly these targets are Quaternary beach ridges and associated foredunes or their fossil equivalents in Coastal Plain sediments.

More recently, airbome gamma-ray radiation and highresolution magnetic surveys were shown to be useful in outlining targets for sampling (Robson and Sampath, 1977; Force and others, 1982; Grosz, 1983; Grosz and others, 1989). Induced polarization is another promising technique for onshore and offshore placer exploration (Wynn and others, 1990).

This report illustrates a method for delimiting prospective placer districts in the United States by use of National Uranium Resource Evaluation (NURE) Hydrogeochemical Stream Sediment Reconnaissance (HSSR) geochemical data and adjunct airborne spectral gamma-ray radiation data.

\section{ACKNOWLEDGMENTS}

The completion of this report was facilitated greatly by the friendly cooperation, encouragement, and suggestions of many interested persons. Discussions of ideas and helpful criticisms were made generously at various stages in this study by Bruce R. Lipin, Klaus J. Schulz, John D. Peper, and Jeffrey N. Grossman. Cole L. Smith provided the 
NURE geochemical data, and Ronald $\mathbf{R}$. Worl provided financial support for the field investigation of some of the geochemical anomalies in the northwestern States. James D. Hoffman provided the NURE geochemical data for the southeastern States.

W. Jason Greenwood assisted with the field studies in the northwestern States and with laboratory analyses of samples. Bruce R. Lipin and Michael P. Foose provided excellent technical reviews of the manuscript in various stages. We wish to express our special gratitude to Linda $\mathbf{J}$. Jacobsen for her critical examination of the text and figures and for making excellent suggestions for improvement.

\section{THE NURE PROGRAM}

\section{BACKGROUND}

The NURE program gathered data to evaluate uranium resources for the United States and to identify areas potentially favorable for uranium deposits (Averett, 1984). Between 1975 and 1983, this U.S. Department of Energy program acquired stream sediment geochemistry and airborne spectral gamma-ray radiation data for the conterminous 48 States and Alaska.

The HSSR, one component of the NURE program, entailed collection and analysis of samples of sediment (stream, soil, talus, playa, and others), ground water, surface water, and vegetation to determine concentrations of uranium and other selected elements (Arendt and others, 1980). These data helped to outline geochemical provinces and to show favorable areas for more detailed investigation. Averett (1984) gives tabulations of areas surveyed during the HSSR and the available information for those areas.

Another component of the NURE program was aerial gamma-ray surveying. These NURE data are the only nationwide information on natural radiation in the environment. The U.S. Geological Survey has reprocessed the aerial gamma-ray data to produce maps showing surface concentrations of potassium $(\mathrm{K}), \mathrm{U}$, and Th for the conterminous United States (Duval and others, 1989, 1990).

Sampling of the HSSR data was reported on $1^{\circ} \times 2^{\circ}$ quadrangles. HSSR data reports were issued for 330 (70.5 percent) of the $4681^{\circ} \times 2^{\circ}$ quadrangles in the 48 conterminous States and in 104 ( 68 percent) of the $1531^{\circ} \times 2^{\circ}$ quadrangles in Alaska. Thus, about 70 percent of the Nation has geochemical coverage. All samples were analyzed for uranium, and nearly all were analyzed also for as many as 59 elements (Averett, 1984). The geochemical data for the westem States are available on compact disc (Hoffman and others, 1991); data for the eastern States are not yet available in this format. There are plans to release these data by 1996 in compact disc format.

Three laboratories analyzed the samples discussed here. Samples from the eastern States of Virginia, North
Carolina, South Carolina, and Georgia were analyzed at the Savannah River Laboratory. Samples from the western States of Washington, Oregon, Idaho, Montana, and Wyoming were analyzed at the Lawrence Livermore National Laboratory and at the Los Alamos National Laboratory (Averett, 1984). Analyses were conducted primarily by instrumental neutron activation analysis, and the precision for all elements except $U$ and $T h$ was \pm 25 percent. This level of precision was adequate for the needs of the NURE program and is considered useful for regional studies, but it is lower than the analytical quality routinely obtainable today (S. Church, U.S. Geological Survey, written commun., December 1992).

\section{DATA LIMITATIONS}

The HSSR data base for each quadrangle contains information on sample types, location coordinates, various descriptive fields, and analytical data. For this report, we did not evaluate the quality of or normalize the data. We searched the data for 35 quadrangles (the Georgetown, South Carolina, quadrangle was not available) from the eastern States for stream-sediment samples (149-micrometer sieve fraction) having concentrations for Ce, Dy (dysprosium), Eu (europium), Hf, La, Lu (lutetium), Sm (samarium), Th, Ti, U, Y (yttrium), and $\mathrm{Yb}$ (ytterbium). Zirconium ( $\mathrm{Zr}$ ) data are not available for these quadrangles.

The data (including $\mathrm{Zr}$ ) were searched for 41 quadrangles covering the westem States. For some of these quadrangles, stream-sediment samples were scarce, and sample density was low. Therefore, other sediment sample types were used to extend areal coverage and increase sample density. These other sample types included wet and dry sediments, dry stream sediments, talus, and soil at various size fractions. The data set generated for this study includes (1) 275 samples of unspecified wet and dry sediments mostly from southern and northern Idaho, (2) 387 dry stream-sediment samples from Washington, southwest Oregon, and south-central Idaho, (3) 606 soil samples mostly from southwestern Idaho and southeastern Oregon, (4) 196 wet stream-sediment samples mostly from central Idaho and northeastern Washington, (5) 1,449 samples of dry sediment predominantly from Montana, (6) 1,156 wet sediment samples from central and northem Idaho, and (7) 3 talus samples.

For the eastern States 33,189 samples and for the western States 44,822 samples met the search criteria. For each sample, elemental data were reported as (1) a positive number (expressed as parts per billion, ppb), (2) zero, (3) a negative number (signifying less than a given level of concentration; that is, $-2,000 \mathrm{ppb}$ ), or (4) no value (analytical data not available). In this study only positive numbers were used; data are discussed in percent format. Ti was consistently reported from the samples from both regions; 
however, not all the REE were analyzed in every sample. For many quadrangles in the westem States only $\mathrm{Zr}$ was provided. Data for Hf were often not available. Where both $\mathrm{Hf}$ and $\mathrm{Zr}$ were available, $\mathrm{Zr}$ was used; where only $\mathrm{Hf}$ was available, it was used. Thus, in the western States, locations of anomalous Hf- and (or) Zr-bearing samples were plotted.

Notably, the mix of sample types in the western States introduces geochemical variability into the data set. Talus and soil sediments, for example, are not comparable to stream-sediment samples because stream sediments represent larger source areas and are subject to vigorous hydraulic sorting. Sorting, in tum, concentrates resistate heavy minerals. For this paper, we did not analyze the potential effects of mixing these diverse sample types. However, this approach does outline known $\mathrm{Ti}, \mathrm{Zr}$, Hf, and REE districts, deposits, and occurrences.

\section{PREVIOUS STUDIES}

Overstreet (1967), Mertie (1975), Houston and Murphy (1977), Force and others (1982), and Owens and others (1990) have shown that monazite and zircon are present in the areas used as examples in this report. Further, they showed that some sediments have undergone extensive weathering that removed much of the labile mineral component (amphiboles and pyroxenes, for example). Force and others (1982) and Owens and others (1990), among others, also document that radioactive monazite and zircon control the gamma-ray aeroradiometric signature of surficially exposed placer heavy-mineral concentrations.

In Pleistocene and Holocene sediments of coastal South Carolina, geochemical anomalies correspond to deposits of heavy minerals in beach-complex sediments identified by Force and others, (1982). Prominent NURE $\mathrm{Ti}-\mathrm{Zr}$ anomalies in southem Virginia and central to northern North Carolina Tertiary sediments along the Fall Zone outline the general area of recent discoveries of heavy-mineral deposits (Berquist, 1987; Carpenter and Carpenter, 1991; Hoffman and Carpenter, 1992). Studies of aeroradiometric anomalies near the North Carolina-South Carolina State line by Owens and others (1990) show that sediments nearest the Fall Zone have the strongest radioactivity and that the regional intensity of the radioactivity decreases toward the coast. That study also confirms that aeroradioactivity anomalies vary with the concentration of monazite in the sediment samples.

Several anomalous REE sites on the lower portion of the Coastal Plain in North Carolina and South Carolina are approximately coincident with known REE-bearing sedimentary phosphorite occurrences such as those shown by Force and others (1982). Staatz and Armbrustmacher (1981) defined an REE province that is coincident with the Fall Zone in South Carolina because of the high monazite content of the sediments.
Much literature exists on the REE, Th, $U$, and gold placers of Idaho and Montana. Most of this literature was generated in the years immediately following World War II when the Nation sought source materials for atomic energy under the sponsorship of the Atomic Energy Commission. Eilertsen and Lamb (1956) offer an overview of this program. Areas known to contain thorite veins, such as the Lemhi Pass and Porthill districts of Idaho and carbonatites in the Mineral Hill district of Idaho (Parker and Baroch, 1971), are anomalous in REE. The Lemhi Pass and Mineral Hill districts extend into western Montana and exhibit REE anomalies there.

Olson and Adams (1962) show locations of Th and REE deposits in the conterminous United States. Their map shows some of the districts and locations described for the western States and some for the eastern States. Guild (1981a, b) gives additional data on the locations of known deposits and districts in both regions. Many geochemical anomalies associated with the Idaho batholith and related granitic rocks correspond to monazite-bearing placer deposits.

Houston and Murphy (1977) discuss the prospects for titaniferous placers in the western States and outline $20 \mathrm{Ti}$ bearing fossil placer deposits of heavy minerals in marine sandstones. These deposits are exclusively in regressivetype marine littoral sediments along the western edge of Upper Cretaceous rocks and contain opaque iron-titanium oxides and zircon as the most abundant minerals, and less abundant rutile, chromite, monazite, tourmaline, garnet, staurolite, amphibole, pyroxene, sphene, apatite, allanite, niobium-bearing opaque minerals, anatase, biotite, brookite, chlorite, epidote, kyanite, pyrite, spinel, and gold (Houston and Murphy, 1977, p. A7). Many of these occurrences appear in Olson and Adams' (1962) compilation because of the associated Th and REE, presumably in monazite, sphene, apatite, and allanite.

\section{METHODOLOGY}

\section{RATIONALE}

This study is based on the hypothesis that elements such as $\mathrm{Ti}$, and $\mathrm{Hf}$ or $\mathrm{Zr}$, in stream-sediment samples indicate the presence of common economic heavy minerals such as ilmenite and rutile, in the case of $\mathrm{Ti}$, and zircon, in the case of $\mathrm{Hf}$ and $\mathrm{Zr}$. The REE are commonly associated with $\mathrm{Y}, \mathrm{Th}$, and $\mathrm{U}$ in heavy minerals such as monazite, xenotime, and allanite. Because $\mathrm{Zr}$ and $\mathrm{Hf}$ possess extraordinary geochemical affinity for each other, they usually indicate the presence of zircon (Vlasov, 1966). Although other commonly occurring heavy and light mineral species can carry these elements as well (for example $\mathrm{Ti}, \mathrm{Hf}$, and $\mathrm{Zr}$ in amphiboles, $\mathrm{Zr}$ and $\mathrm{Hf}$ in pyroxenes, and $\mathrm{REE}, \mathrm{U}$, and $\mathrm{Th}$ 


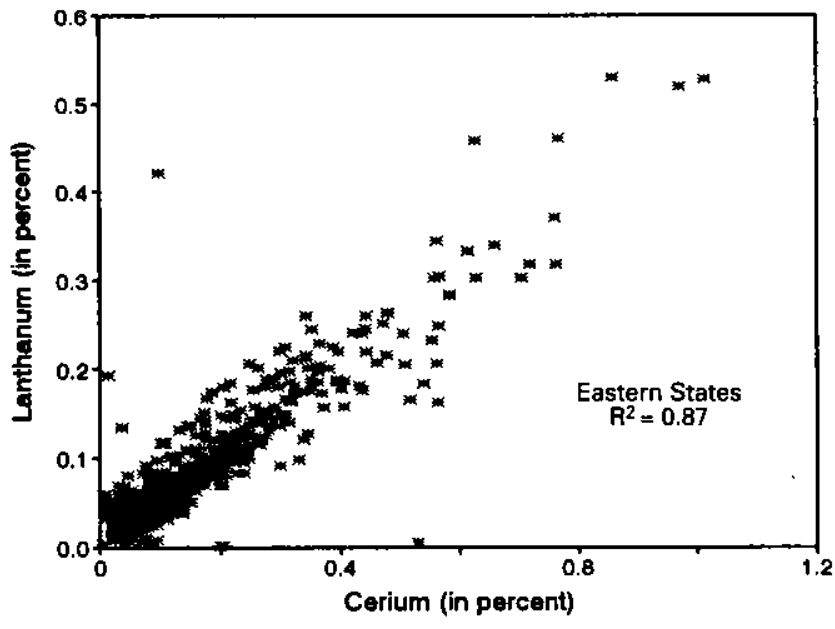

Figure 1. The relation between cerium and lanthanum in samples having greater than 0.05 percent REE from the eastern States.

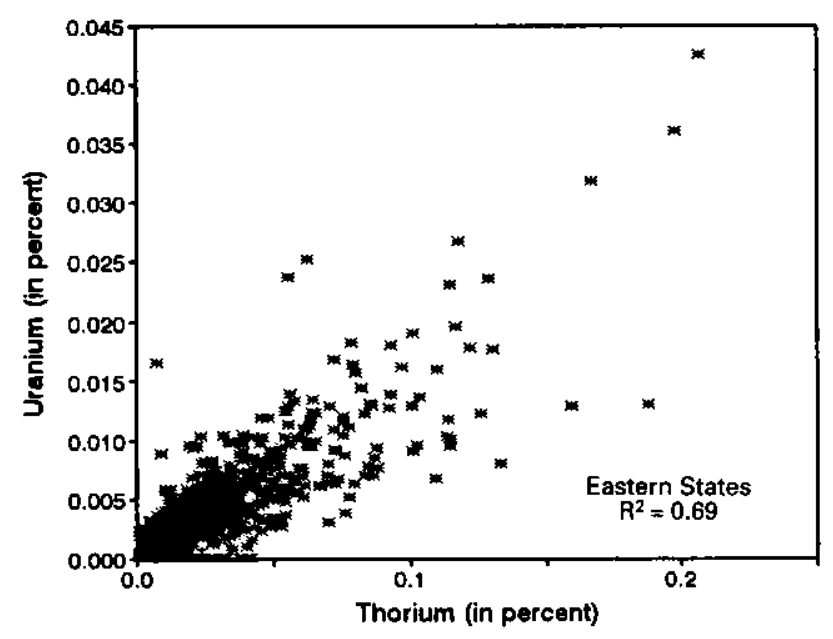

Figure 3. The relation between thorium and uranium in samples having greater than 0.05 percent REE from the eastem States.

in apatite), they typically contain only trace abundances of these elements.

NURE Ti distributions are consistent with known oxide occurrences. $\mathrm{Ti}$ occurrences, however, may not always be present as ilmenite or rutile. This consideration could be important especially in arid parts of the western United States where sphene, magnetite, and Ti-augite, for example, may be common in soils and sediments.

Figure 1 displays the relation between $\mathrm{Ce}$ and $\mathrm{La}$ concentrations for 2,652 samples from the eastern States. These samples have greater than 0.05 percent REE. The $\mathrm{R}^{2}$ is 0.87 . Excluding three samples that have a $\mathrm{Ce}$ to $\mathrm{La}$ ratio greater than 110 to 1 , the Ce-La ratio of this population is about 2 to 1. Overstreet (1967) states that the monazite in the southeastern United States has a Ce-La ratio of about 2.1 to 1 . The scatter shown on the diagram is a probable function of compositional variability in monazite (Overstreet, 1967),

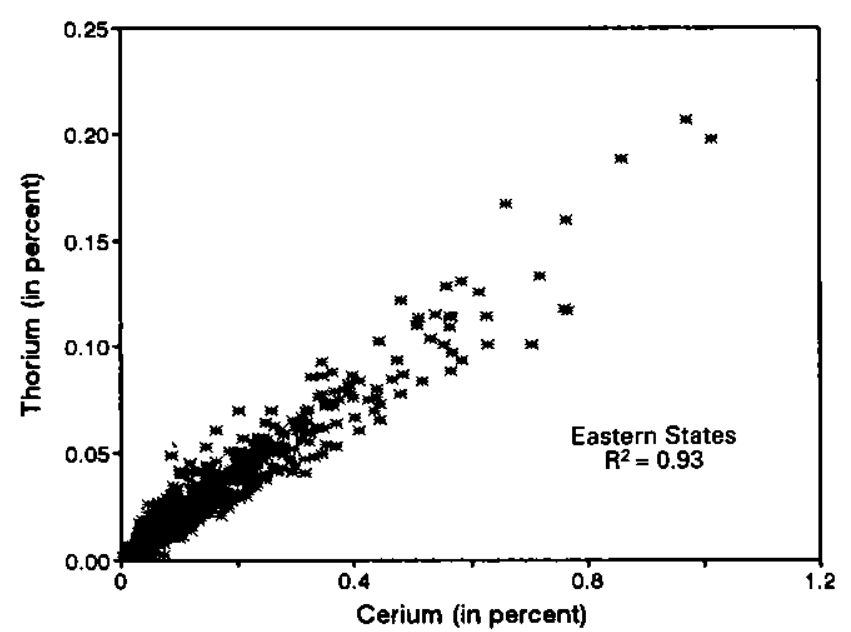

Figure 2. The relation between cerium and thorium in samples having greater than 0.05 percent REE from the eastern States.

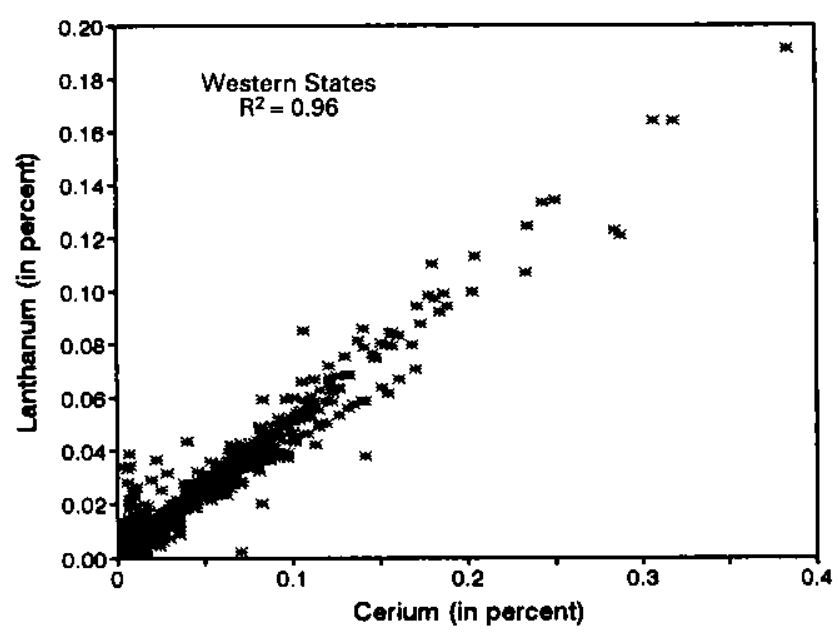

Figure 4. The relation between cerium and lanthanum in samples having greater than 0.0096 percent REE from the westem States.

the presence of allanite (known to occur in the area), and the presence of low-Th, REE-bearing phosphorite in coastal sediments. The relation between $\mathrm{Ce}$ and $\mathrm{Th}$ for these samples is shown in figure 2 . The $\mathrm{R}^{2}$ is 0.93 and shows that monazite controls the distribution of Th. Figure 3 displays the relation between $T h$ and $U$ for these samples. An $R^{2}$ of 0.69 indicates that monazite is also an important contributor of $U$.

Figure 4 displays the relation between $\mathrm{Ce}$ and $\mathrm{La}$ in 4,072 samples from the western States. These samples have greater than 0.0096 percent REE. The $\mathrm{R}^{2}$ is 0.96 . The Ce-La ratio of this population is about 2 to 1 , which agrees with that for monazite. Allanite, thorite, monazite, zircon, apatite, and several other REE- and Th-bearing minerals are present in the western States, and their relative abundances and varied compositions influence the minor scatter on the diagram. The relation between $\mathrm{Ce}$ and $\mathrm{Th}$ for these samples 


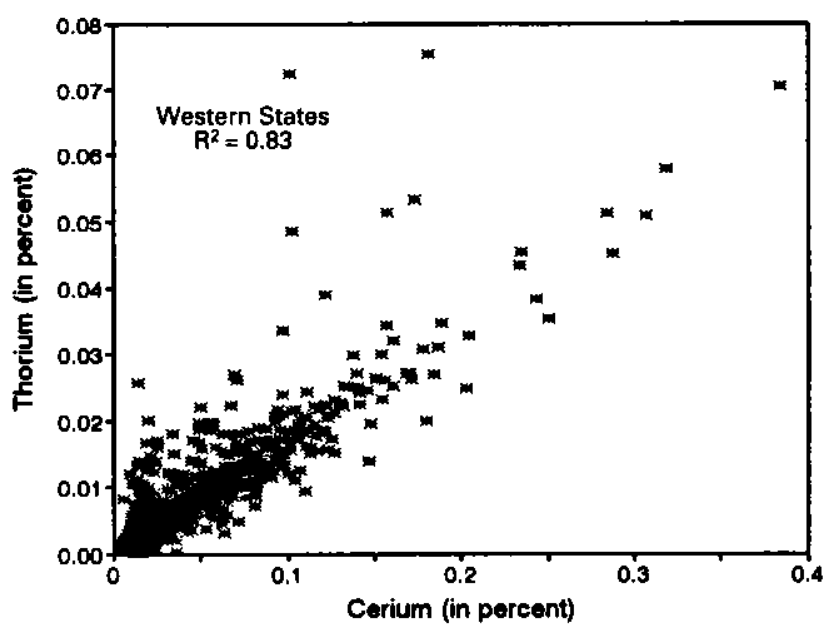

Figure 5. The relation between cerium and thorium in samples having greater than 0.0096 percent REE from the western States.

(excluding one sample having 4.44 percent $\mathrm{Th}$ ) is shown in figure 5. The $R^{2}$ is 0.83 .

Zircon occurs in igneous, metamorphic, and terrigenous clastic sediments. Many geologic investigations, including those of Overstreet (1967), Mertie (1975), Force and others (1982), Owens and others (1990), and Grosz and others (1992), document the presence of zircon in eastern quadrangle crystalline and sedimentary rocks. Houston and Murphy (1977) show that zircon is present in Cretaceous sandstones in the western States; many other geological and mineral resource investigations refer to the presence of zircon in the rocks and sediments of the western United States. The presence of zircon in this area is indicated also by the HSSR geochemical data. Figure 6 displays the relation between $\mathrm{Zr}$ and $\mathrm{Hf}$ for 661 samples from the western States. The $\mathrm{Zr}-\mathrm{Hf}$ ratio for zircons generally varies from 15 to 150 (Vlasov, 1966); for the western suite of samples, the Zr-Hf ratio is about 20 , indicating an igneous signature. The $R^{2}$ for this relation is $0.90 . \mathrm{Zr}$ and $\mathrm{Hf}$ also occur in dispersed form in Ti minerals, amphiboles, and pyroxenes (Vlasov, 1966) and thus may contribute to the scatter.

The relation between $\mathrm{Ce}$ and Th shown in figures 2 and 5 shows that Th-rich monazite is the source for Th. The relation between $T h$ and $U$ in the samples from the eastem States (fig. 3) suggests that monazite is also a principal source of U. Monazite controls the distribution of Th, and therefore the radioactivity, of the sediments in both regions. This agrees with work by Force and others (1982) and Owens and others (1990) discussed above.

\section{TECHNIQUE}

We attempted the identification of anomalous outliers by using several statistical methods. Initial attempts to analyze whole data sets for both western and eastern regions resulted in cutoff thresholds that were too high to generate

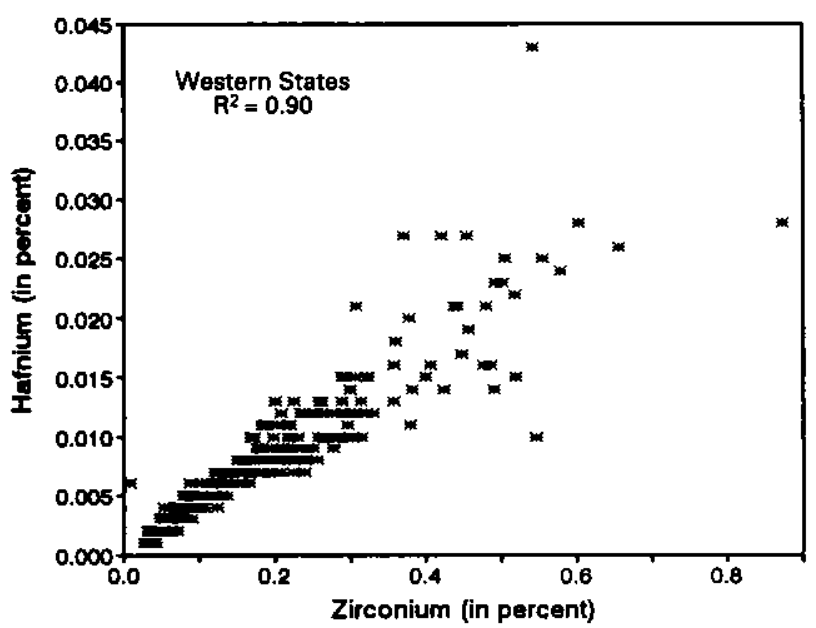

Figure 6. The relation between zirconium and hafnium for 661 samples from the western States.

meaningful distribution patterns. This result occurred because high elemental values associated with crystalline terranes produced cutoff thresholds that masked significant variations on the sedimentary terranes that have generally lower overall abundances. To overcome the controlling effect of the underlying geology, the statistical analysis of data was done on a quadrangle basis. This approach eliminated some, but not all, of the problems related to changes in thresholds. In western Virginia, for example, high values associated with Blue Ridge province rocks masked the anomalies of Valley and Ridge province rocks to the west.

For each eastem quadrangle, the data were rank ordered, and cumulative frequency plots were constructed to identify anomalous outliers. In the western States, three different methods of defining anomalous values produced similar geographic distribution patterns. These methods were (1) using 2 standard deviations above the mean, (2) using cumulative frequency plots, or (3) isolating the upper 5 th, 7 th, and 10 th percentile values. Although producing similar distributions, the three methods result in different frequencies of anomalous points (that is, the size of the cluster) in a given geographic area. By trial and error, the upper 10th percentile for each element was found as the most effective for defining anomalies in the western States.

For the 35 quadrangles from the eastern States, cumulative frequency curves for individual elements showed 3,142 samples having REE ranging from greater than 0.05 to 1.71 percent, 3,619 samples having $\mathrm{Ti}$ ranging from greater than 1.5 to 9.96 percent, and 1,984 samples having $\mathrm{Hf}$ ranging from greater than 0.015 to 0.4806 percent as anomalous. For the 41 quadrangles from the westem States, the upper 10th percentile yielded 4,358 samples having REE ranging from greater than 0.0096 to 2.65 percent; 4,254 samples having $\mathrm{Ti}$ ranging from greater than 0.24 to 6.01 percent, and 4,286 samples having $\mathrm{Hf}$ or $\mathrm{Zr}$ ranging from greater than 0.0007 to 0.8742 percent as anomalous. 
Sample location coordinates, along with analytical data for the REE, Ti, and Hf or $\mathrm{Zr}$, are given by Grosz (1993a, b); data for the eastern States also include $U$ and $T h$. These data sets define (1) source rocks for possible placer deposits and (2) anomalous concentrations of heavy minerals in sediments that may indicate heavy-mineral deposits.

\section{DISCUSSION}

The distributions of the anomalous element concentrations in the eastern and westem States are presented in plates 1 and 2 (in pocket), respectively. Boundaries of the physiographic provinces, locations of geomorphic features, and areas having known titanium, hafnium (indicative of zircon), and REE (indicative of monazite) deposits, districts, and occurrences in the eastern States are shown on plate 1. General locations of known titanium, zircon or hafnium (indicatibe of zircon), and REE (indicative of monazite) deposits, districts, and occurrences in the western States are shown on plate 2 .

\section{THE EASTERN STATES}

Plate 1 shows the locations of 3,619 samples having greater than 1.5 percent $\mathrm{Ti}, 3,142$ samples having greater than 0.05 percent REE, and 1,984 samples having greater than 0.015 percent $\mathrm{Hf}$. Several distinct northeast-southwesttrending zones of individual, paired, or multiple elements, along with many smaller, more localized anomalous clusters, are shown.

The Blue Ridge province (BR; pl. 1) rocks consist of Proterozoic gneiss and late Proterozoic and lower Paleozoic stratified (mainly marine) sequences. They form a Ti-rich province. The southern part (south of the Virginia-North Carolina State line) of this province is richer in REE than the northern part.

The Piedmont province (P; pl. 1) consists of Mississippian and Pennsylvanian metamorphic complexes (particularly in western North Carolina, South Carolina, and Georgia) that are mostly schist, phyllite, felsic and mafic gneiss, migmatite and felsic gneiss, and middle Paleozoic granitic rocks. This area is also an REE province. Cambrian eugeosynclinal, volcanic, Mississippian, and Triassic mafic intrusive rocks of the eastern Piedmont province and Carolina slate belt (CSB) also have elevated $\mathrm{Ti}$ values; the trends, however, are more localized than those in the Proterozoic and lower Paleozoic (BR) rocks to the west.

$\mathrm{Hf}$ and $\mathrm{Ti}$ anomalies are coupled in the BR of westem Virginia. To a lesser extent, Hf anomalies correlate with TiREE anomalies in southern BR rocks. In contrast, Hf anomalies are commonly associated with $\mathrm{Ti}$ and Ti-REE anomalies in western Piedmont rocks, particularly in South Carolina and Georgia. Granitic rocks in the eastern Piedmont are characterized by anomalous $\mathrm{Ti}$ and $\mathrm{Hf}$; REE anomalies are scarce and widely dispersed. Crystalline rocks of the Piedmont province, specifically Silurian to Pennsylvanian intrusive rocks, are important Hf (and REE) sources in South Carolina. Because the anomalies in the Blue Ridge and Piedmont provinces and the Carolina slate belt are associated with crystalline rocks, the potential for large-volume Ti-Hf-REE placer deposits of heavy minerals is more limited than that in the unconsolidated sediments of the Coastal Plain province to the east. It is likely, however, that workable fluvial placers of primarily monazite and zircon exist in the western Piedmont of North Carolina, South Carolina, and Georgia.

Valley and Ridge province (VR; pl. 1) rocks in westem Virginia and northwestern Georgia notably lack anomalous values. This absence is probably a function of high cutoff thresholds for quadrangles having both crystalline and sedimentary rocks as discussed previously.

Coastal Plain (CP; pl. 1) sediments range in age from Cretaceous to Holocene east of the Fall Zone (FZ; pl. 1), which is the western boundary of Cretaceous and Tertiary sediments, at an average altitude of $73 \mathrm{~m}$. These sediments contain a series of anomalies that correspond to locations of known ilmenite-rutile-zircon-monazite-bearing marine placer deposits; other anomalies suggest prospective areas for further exploration.

$\mathrm{Ti}, \mathrm{Hf}$, and to a lesser extent REE anomalies in eastern Coastal Plain sediments in southeastern Virginia correlate with heavy-mineral occurrences in barrier-sand-ridge and shelf-fine-sand facies deposits (Grosz, 1983). Other anomalies in the Lower Cretaceous to Pleistocene sediments in the Coastal Plain of Virginia indicate important areas for exploration. To the south, anomalous values along the Suffolk scarp (SS; pl. 1) are associated with beach ridge complex deposits. An undeveloped heavy-mineral placer deposit located along this scarp in North Carolina is reported to have 35 million metric tonnes of beach sand, or approximately 400,000 metric tonnes of contained $\mathrm{TiO}_{2}$ (Fantel and others, 1986). These anomalies extend intermittently to the southeastern to northern flank of the Cape Fear arch (CFA; pl. 1).

Miocene sediments of the Coastal Plain of Virginia host many northwest-southeast-trending geochemical anomalies indicative of possible placer resources. In North Carolina, anomalies in Miocene sediments east of, and paralleling, the Fall Zone also extend south to the vicinity of the Cape Fear arch. Many of these anomalies are approximately coincident with the late Tertiary to early Quaternary Surry scarp (SUS; pl. 1) as shown by Blackwelder and Cronin (1981). These anomalies consist of high Ti, less frequent Hf, and scarce REE. The low REE (and low Th) content of these sediments implies that gamma radiation surveys would be of little help in defining prospective areas for placer exploration. NURE airborne radiation data given by Duval and others $(1989,1990)$ confirm this. 
Further south along the Fall Zone, in sediments predominantly of Cretaceous age, the general character of the anomalies changes to one consisting of high REE-Hf, and scarce Ti. Eocene sediments, particularly in South Carolina and Georgia, also have anomalous concentrations of these elements, although clusters are more scattered in Eocene than in Cretaceous sediments.

One deposit of monazite, ilmenite, rutile, staurolite, and gravel already has been mined in the Fall Zone at Horse Creek near Aiken, South Carolina (Mertie, 1975). This deposit, in Fall Zone sediments near the South CarolinaGeorgia State line, is underlain and surrounded by sediments of Cretaceous age that directly overlie the crystalline rocks of the Piedmont and contains heavy minerals reconcentrated from Cretaceous formations.

In contrast to the Virginia and North Carolina Coastal Plain sediments, where geochemical Ti-Hf anomalies predominate, the sediments in the Coastal Plain of South Carolina and Georgia have predominantly Hf-REE anomalies.

NURE spectral aeroradiometric surveys (Duval and others, 1989, 1990) also show anomalous $U$ and Th signatures over many Coastal Plain areas outlined by geochemical anomalies. Total-count aeroradiometric data also agree (Force and others, 1982; Owens and others, 1990). Therefore, aeroradiometric data provide useful guides for exploration in Coastal Plain areas lacking geochemical coverage.

\section{THE WESTERN STATES}

In contrast to the regionally continuous and coherent anomalous trends in the eastern States, trends in the western States are in smaller clusters of varied geographic orientation. Plate 2 shows the locations of 4,254 samples having greater than 0.24 percent $\mathrm{Ti}, 4,358$ samples having greater than 0.0096 percent REE, and 4,286 samples having greater than 0.0007 percent $\mathrm{Zr}$ or $\mathrm{Hf}$ (henceforth $\mathrm{Zr}$ ) in the western States. Anomalies dominated by individual, paired, or multiple elements are evident.

Prominent REE anomalies in central Idaho (pl. 2) correlate with locations of known alluvial heavy-mineral deposits in valley fills. These deposits contain monazite and euxenite as principal REE- and Th-bearing minerals derived from the Cretaceous granitic rocks of the Idaho batholith. Other radioactive minerals in these deposits include brannerite, xenotime, samarskite, and zircon; nonradioactive heavy minerals include magnetite, ilmenite, columbite-tantalite, gamet, and gold. The most common opaque heavy mineral in these alluvial deposits is ilmenite, contrary to the expected magnetite, which is more common in the granitic basement (Kiilsgaard and Hall, 1986).

In the western States, prominent geochemical anomalies are also associated with Tertiary and Quaternary volcanic sequences, particularly in southern Oregon, southern Idaho, and south-central Idaho. In southeastern Oregon, a 48-km-long north-northeast-trending series of Ti (A, pl. 2) anomalies was sampled in the summer of 1992 to confirm the projected mineral associations with the geochemical anomalies. In center of this anomalous trend, near Borax Lake in the Alvord desert, sediment samples yielded a magnetite-titanomagnetite-rich concentrate upon panning. The rocks adjoining the valley (graben) floor to the west are Pliocene basalt of Steens Mountain that contain titanomagnetite-bearing dikes that parallel the valley. Significant volumes of detrital magnetite and titanomagnetite may be present in Quaternary valley fill sediments. About 48 to 72 $\mathrm{km}$ east-northeast of this trend is another trend of $\mathrm{Ti}$ anomalies (B, pl. 2) associated mostly with Tertiary volcanic rocks. Further north in southeastern Oregon, over Tertiary continental deposits, $\mathrm{Ti}$ anomalies are less prominent; $\mathrm{Zr}$ predominates, and REE anomalies are less frequent. Valley fills in this area could be sites of important zircon concentrations. To the west of the Ti anomalies in the Alvord desert area (A, pl. 2), Quaternary valley fill sediments adjacent to predominantly $\mathrm{Zr}$ and $\mathrm{REE}$ anomalous Tertiary rocks show potential for placer exploration. In southern Idaho, Tertiary rhyolite hosts a series of predominantly REE and $\mathrm{Zr}$ anomalies (C, pl. 2).

In south-central Idaho, in the area of the Snake River Plain, Quaternary volcanic rocks are generally lacking significant anomalous clusters. An exception occurs in area D (pl. 2) where a significant concentration of $\mathrm{Zr}, \mathrm{Ti}$, and REE anomalies is located near the northern edge of the Snake River Plain. The nature of the deposits responsible for these anomalies is not known; however, the strong clustering of these anomalies warrants investigation.

Areas underlain by Cretaceous granitic rocks, border gneiss of the Idaho Batholith, and Quatemary sediments surrounded by these rocks in southwestern Montana contain many $\mathrm{REE}$ and $\mathrm{Zr}$ anomalies and less frequent $\mathrm{Ti}$ anomalies (E, pl. 2). Middle Precambrian stratified sequences in northwestern Montana and northern Idaho (F, pl. 2) host many north-northwest- and west-northwest-trending small-scale anomalies of varied composition. In west-central Montana a large, generally north-south-trending sinuous cluster $(\mathrm{G}, \mathrm{pl}$. 2) of predominantly $\mathrm{REE}$ and $\mathrm{Zr}$ anomalies, and fewer $\mathrm{Ti}$ anomalies, cuts across a series of rock types. These anomalies are associated mostly with latest Cretaceous granitic rocks; however, to the south they trend onto stratified sequences ranging in age from Precambrian to upper Paleozoic. To the north they extend onto continental deposits of Miocene age. Several anomalous localities in this region of Montana are associated with known placer or hard rock occurrences, prospects, or mines containing Th and REE (Olson and Adams, 1962). The distribution of geochemical anomalies, however, suggests a much larger area is suitable for further exploration. The prospects for placer deposits here, as elsewhere on the crystalline and hard rock terrane of western Montana, are best in areas where large volumes of valley fill sediment exist next to the source rocks. 
Some NURE Ti and Ti-Zr-REE anomalies coincide with titaniferous deposits documented by Houston and Murphy (1977). However, the NURE data do not detect most of the known $\mathrm{Ti}$ deposits. Probable reasons for this lack of expression are the small size of the deposits, low sampling density, and high cutoff thresholds selected for $\mathrm{Ti}$ in quadrangles having both crystalline and sedimentary rocks, as discussed previously.

Large areas having significant concentrations of $\mathrm{Ti}, \mathrm{Zr}$, and REE, individually or in combination, are outlined by the NURE data in Cretaceous stratified sequences and in Tertiary continental deposits as defined by King and Beikman $(1974 a, b)$. To our knowledge the bulk of Montana underlain by these deposits has not been examined for potential placer resources. Lower Cretaceous deposits contain several clusters (H, I, J, K, L, M, pl. 2) of Ti-Zr-REE anomalies, along with locally anomalous groups composed of $\mathrm{Zr}, \mathrm{Zr}-\mathrm{REE}$, or Ti-REE. Upper Cretaceous units in northern and east-central Montana also host significant clusters (N, O, P, Q, R, pl. 2) of single or multiple element geochemical anomalies. In easternmost Montana, Upper Cretaceous units host a significant cluster of Ti-Zr-REE anomalies ( $S$, T, U, pl. 2).

Miocene age continental deposits in southwestem Montana (particularly those near Cretaceous granites), Precambrian orthogneiss and paragneiss, and Cretaceous volcanic rocks have elévated $\mathrm{REE}-\mathrm{Zr}$, Ti-Zr-REE, and $\mathrm{Ti}-\mathrm{Zr}$ values, respectively. Oligocene deposits in southeastern Montana (V, pl, 2) also host localized concentrations of these elements.

Most individual or small groups of anomalies, as well as the larger clusters of anomalies discussed above in central and eastern Montana, are associated with clastic sedimentary sequences. Spectral aeroradiometric data (Duval and others, 1989, 1990) show Th and U, and, to a lesser extent, $\mathbf{K}$ anomalies coincident with these areas of geochemical anomalies. As there are few geomorphic and geologic indicators for selecting placer exploration targets in this region, the combination of geochemical and geophysical data can be used as an altemate tool for exploration.

\section{CONCLUSIONS}

NURE-HSSR geochemical data are well suited for outlining areas within the United States for Ti-Hf-REEbearing deposits of placer heavy minerals. Together with geologic, topographic, and airborne geophysical information, the data are a powerful tool for exploration purposes.

Geochemical data for $\mathrm{Ti}, \mathrm{Zr}$ and (or) $\mathrm{Hf}$, and REE in the NURE HSSR data base for the United States, are reliable indicators of ilmenite (and other Ti-bearing oxides), zircon, and monazite (and other REE-bearing minerals), respectively, in crystalline and sedimentary rocks and in unconsolidated sediments. Samples from test areas in the eastern and western United States show the presence of zircon and monazite, respectively. The effectiveness of this integrated placer exploration method is underscored by its capability to locate known placer deposits and districts in the eastern and western States. The geochemical and spectral aeroradiometric signatures of known deposits of heavy minerals are identified over large portions of the Atlantic Coastal Plain and in the western United States.

In the western United States, $\mathrm{Ti}, \mathrm{Hf}, \mathrm{Zr}$, and REE anomalies occur in a broad spectrum of geologic settings. Unusually high and areally extensive concentrations of $\mathrm{Ti}$ are associated with Miocene volcanic rocks in southeastern Oregon, and $\mathrm{Ti}, \mathrm{Zr}$, and REE are associated with Quaternary volcanic and Pliocene felsic volcanic rocks in southern Idaho. Large Quatemary valley fills next to these anomalous rocks may contain commercial accumulations of detrital heavy minerals. Large portions of central and western Montana have geochemical anomalies suggestive of exploration potential.

The geochemical data clearly outline the area of $\mathrm{Ti}-\mathrm{Zr}$ bearing heavy-mineral deposits near the North CarolinaVirginia State line, whereas gamma-ray radiation surveys do not because gamma-ray surveys cannot detect the very low levels of monazite concentration and associated low Th levels in these deposits. Thus, the NURE HSSR data can effectively help locate Ti-bearing placer deposits that do not contain appreciable quantities of radioactive heavy minerals (that is, monazite \pm zircon).

Examination of highly anomalous samples for any given element, as done in this paper, excludes much valuable information on potential large-volume, low-grade deposits of heavy minerals, particularly in Cretaceous and Tertiary sediments in which geochemical expression comparatively is subdued. Examination of the 70th to 90th percentile of the populations reveals persistent anomalies in Atlantic Coastal Plain sediments. The 50th to 90th percentile over some midcontinent and western areas shows similar geochemical signatures. Large areas in northeastern Kansas and eastern Nebraska, for example, may also have exploration potential for $\mathrm{Ti}, \mathrm{Hf}$, and REE. The results of this study suggest that the potential for Ti-Hf-REE-U-Th-bearing placer heavy-mineral deposits in surficially exposed sediments and sedimentary rocks in the United States may be much greater than previously recognized.

\section{REFERENCES CITED}

Arendt, J.W., Butz, T.R., Cagle, G.W., Kane, V.E., and Nichols, C.E., 1980, Hydrogeochemical and stream sediment reconnaissance procedures of the uranium resource evaluation project: U.S. Department of Energy, GJBX-32(80), 53 p.

Averett, W.R., 1984, National uranium resource evaluation guide to data reports of the hydrogeochemical and stream sediment reconnaissance: U.S. Department of Energy, GJBX-5(84), $119 \mathrm{p}$. 
Berquist, C.R., Jr., 1987, Minerals in high-level gravel deposits along the Fall Zone of Virginia: Virginia Minerals, v. 33, p. $37-40$.

Blackwelder, B.W., and Cronin, T.M., 1981, Atlantic Coastal Plain geomorphology illustrated by computer-generated block diagrams: U.S. Geological Survey Miscellaneous Field Studies Map MF-1242, scale 1:1,000,000.

Carpenter, R.H., and Carpenter, S.F., 1991, Heavy mineral deposits in the upper coastal plain of North Carolina and Virginia: Economic Geology, v. 86, no. 8, p. 1657-1671.

Duval, J.S., Jones, W.J., Riggle, F.R., and Pitkin, J.A., 1989, Equivalent uranium map of the conterminous United States: U.S. Geological Survey Open-File Report 89-478, 10 p., scale $1: 2,500,000$.

1990 , Potassium and thorium maps of the conterminous United States: U.S. Geological Survey Open-File Report 90338,16 p., scale $1: 2,500,000$.

Eilertsen, D.E., and Lamb, F.D., 1956, A comprehensive report of exploration by the Bureau of Mines for thorium and black mineral deposits: U.S. Atomic Energy Commission, RME $3140,46 \mathrm{p}$.

Fantel, R.J., Buckingham, D.A., and Sullivan, R.E., 1986, Titanium minerals availability-Market economy countries: U.S. Bureau of Mines Information Circular 9061, $48 \mathrm{p}$.

Force, E.R., Grosz, A.E., Loferski, P.J., and Maybin, A.H., 1982, Aeroradioactivity maps in heavy-mineral explorationCharleston, South Carolina, area: U.S. Geological Survey Professional Paper 1218, 19 p.

Grosz, A.E., 1983, Application of total-count aeroradiometric maps to the exploration for heavy-mineral deposits in the coastal plain of Virginia, with a section on Fieldspectrometer-data reduction, by K.L. Kosanke: U.S. Geological Survey Professional Paper 1263, 20 p.

1993a, NURE stream sediment geochemical data indicative of prospective terranes for Ti-Zr-REE placer exploration in selected regions of the United States: U.S. Geological Survey Open-File Report 93-240-A, 158 p. (paper copy).

1993b, NURE stream sediment geochemical data indicative of prospective terranes for Ti-Zr-REE placer exploration in selected regions of the United States: U.S. Geological Survey Open-File Report 93-240-B, (diskette copy includes manuscript text and data).

Grosz, A.E., Cathcart, J.B., Macke, D.L., Knapp, M.S., Schmidt, Walter, and Scott, T.M., 1989, Geologic interpretation of the gamma-ray aeroradiometric maps of central and northern Florida: U.S. Geological Survey Professional Paper 1461, 48 p.

Grosz, A.E., San Juan, F.C., Jr., and Reid, J.C., 1992, Heavy-mineral concentrations associated with some gamma-ray aeroradiometric anomalies over Cretaceous sediments in North Carolina-Implications for locating placer mineral deposits near the Fall Zone: U.S. Geological Survey Open-File Report 92-396, $27 \mathrm{p}$.

Guild, P.W., 1981a, Preliminary metallogenic map of North America-A numerical listing of deposits: U.S. Geological Survey Circular 858-A, 93 p.

1981b, Preliminary metallogenic map of North AmericaAn alphabetical listing of deposits: U.S. Geological Survey Circular 858-B, 72 p.

*U.S. G.P.0.:1995-387-030:63
Hoffman, C.W., and Carpenter, R.H., 1992, Heavy-mineral deposits in the Bailey area, Nash and Wilson Counties, North Carolina, in Dennison, J.M., and Stewart, K.G., eds., Geologic field guides to North Carolina and vicinity: Chapel Hill, North Carolina, Department of Geology, University of North Carolina at Chapel Hill, Geologic Guidebook No. 1, p. $49-63$.

Hoffman, J.D., Gunnells, G.B., and McNeal, J.M., 1991, National geochemical data base-National Uranium Resource Evaluation data for the conterminous western United States: U.S. Geological Survey Digital Data Series DDS-1.

Houston, R.S., and Murphy, J.F., 1977, Depositional environment of Upper Cretaceous Black sandstones of the western interior: U.S. Geological Survey Professional Paper 994-A, 29 p.

Kiilsgaard, T.H., and Hall, W.E., 1986, Radioactive black sand placer deposits of the Challis $1^{\circ} \times 2^{\circ}$ quadrangle, Idaho: U.S. Geological Survey Open-File Report 86-0633, 13 p.

King, P.B., and Beikman, H.M., 1974a, Geologic map of the United States, exclusive of Alaska and Hawaii: U.S. Geological Survey Special Geologic Map, 3 sheets, scale $1: 2,500,000$.

$1974 \mathrm{~b}$, Explanatory text to accompany the geologic map of the United States: U.S. Geological Survey Professional Paper $901,39 \mathrm{p}$.

Mertie, J.B., Jr., 1975, Monazite placers in the southeastern Atlantic States: U.S. Geological Survey Bulletin 1390, 41 p.

Olson, J.C., and Adams, J.W., 1962, Thorium and rare earths in the United States, exclusive of Alaska and Hawaii: U.S. Geological Survey Mineral Investigations Resource Map MR-28, with explanatory pamphlet, scale 1:3,168,000.

Overstreet, W.C., 1967, The geologic occurrence of monazite: U.S. Geological Survey Professional Paper 530, 327 p.

Owens, J.P., Grosz, A.E., and Fisher, J.C., 1990, Aeroradiometric map and geologic interpretation of part of the Florence and Georgetown $1^{\circ} \times 2^{\circ}$ quadrangle, South Carolina: U.S. Geological Survey Miscellaneous Investigations Series Map I1948-B, scale 1:250,000.

Parker, J.G., and Baroch, C.T., 1971, The rare-earth elements, yttrium, and thorium-A materials survey: U.S. Bureau of Mines Information Circular 8476, 92 p.

Robson, D.F., and Sampath, N., 1977, Geophysical response of heavy-mineral sand deposits at Jerusalem Creek, New South Wales: Bureau of Mineral Resources Joumal of Australian Geology and Geophysics, v. 2, p. 149-154.

Staatz, M.H., and Armbrustmacher, T.J., 1981, Preliminary map of rare-earth provinces in the conterminous United States: U.S. Geological Survey Open-File Report 79-576-T, scale $1: 5,000,000$.

Vlasov, K.A., ed., 1966, Geochemistry and mineralogy of rare elements and genetic types of their deposits [translated from Russian by Z. Lerman and Y. Brenner, Israel Program for Scientific Translations]: Jerusalem, Israel, 1633 p.

Wynn, J.C., Grosz, A.E., and Carlson-Foscz, V.L., 1990, Induced polarization response of some titanium-bearing placer deposits in the southeastern United States, in Fink, J.B., ed., Induced polarization-Application and case histories; Investigations in geophysics: Tulsa, Society of Exploration Geophysicists, no. 4, p. 280-303. 





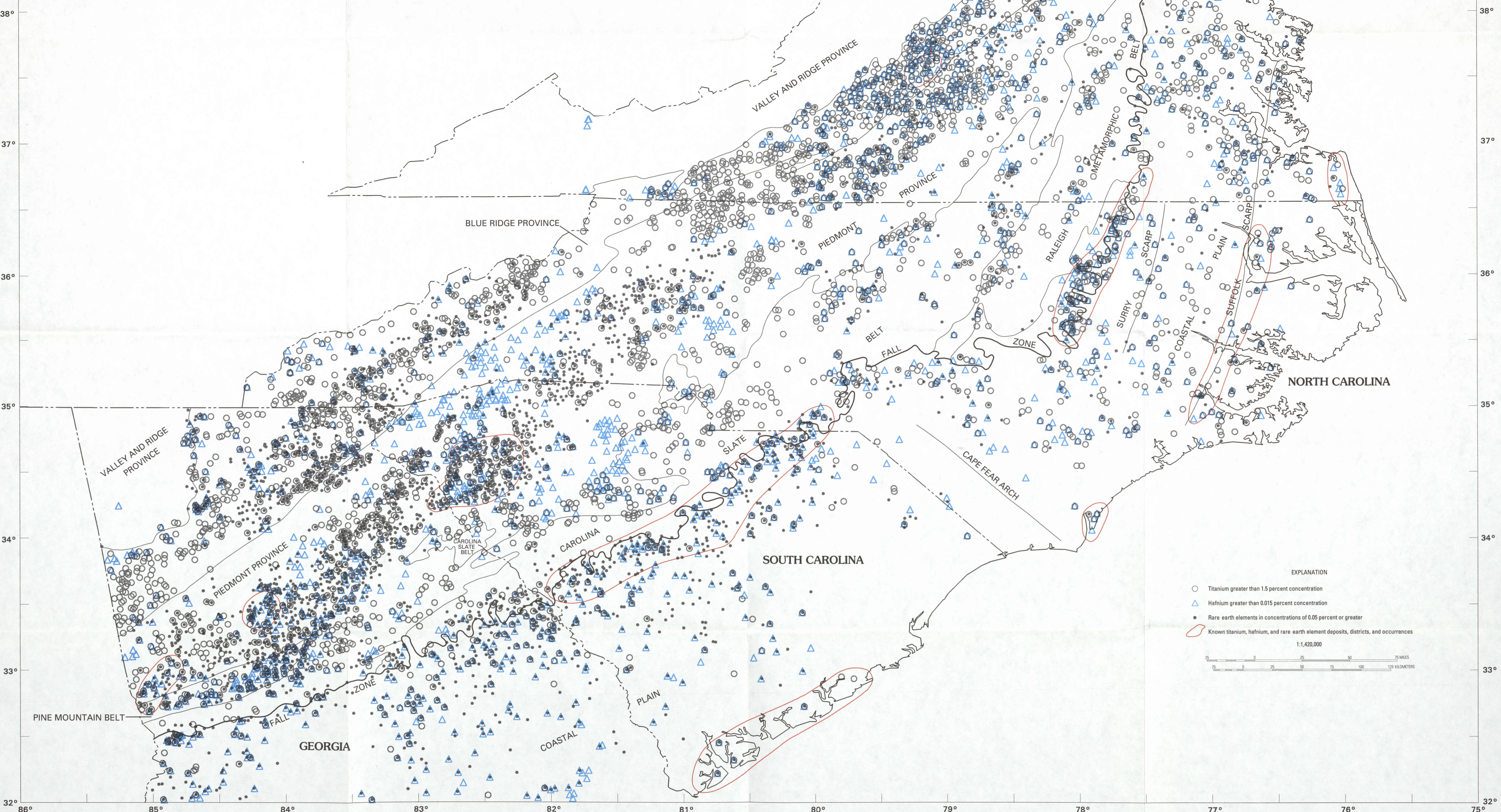

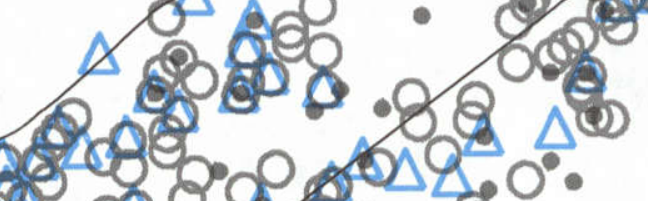

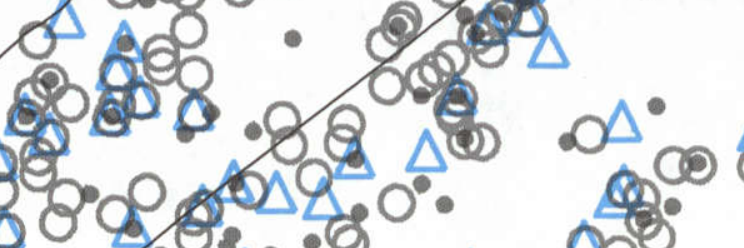

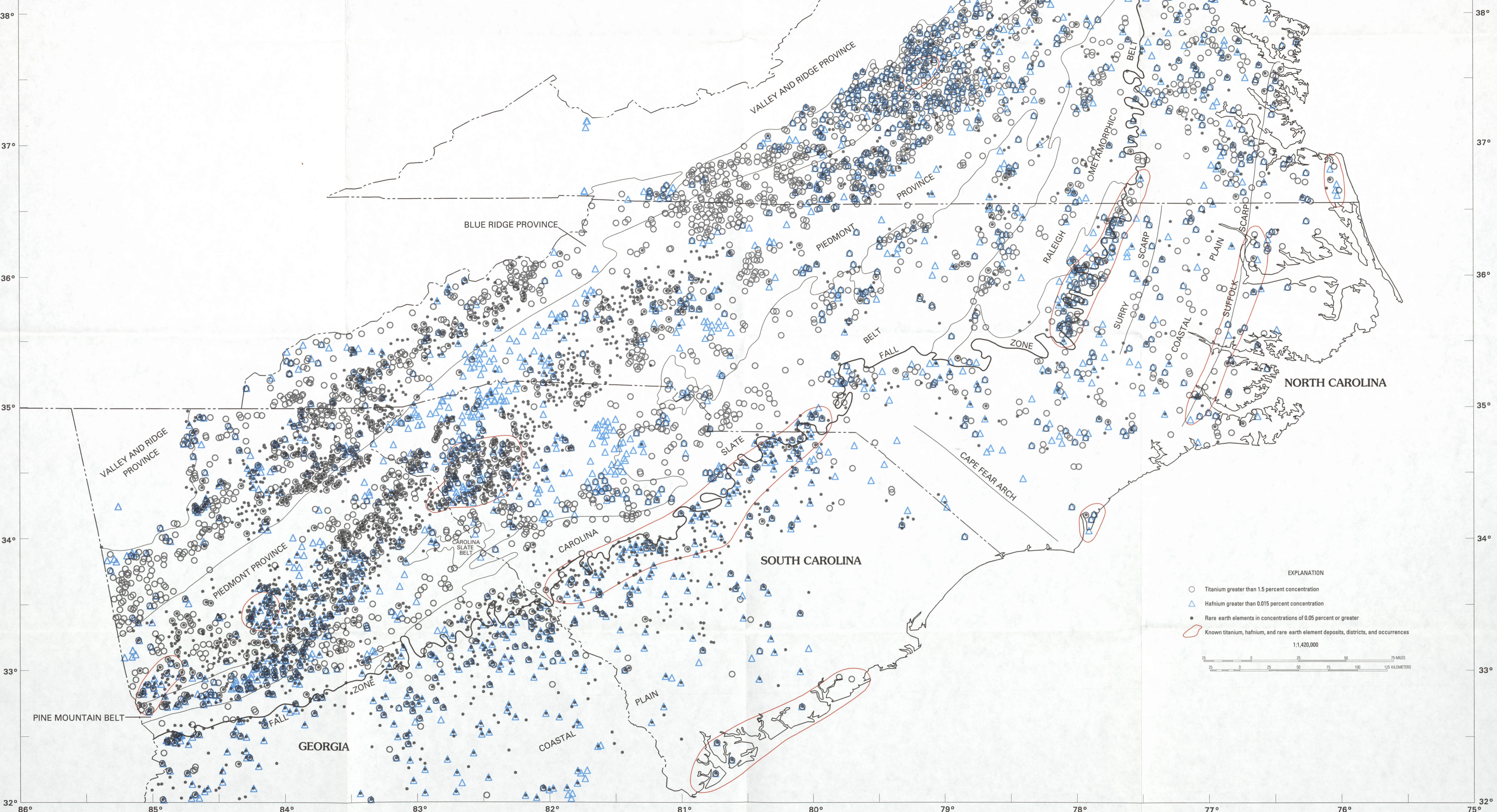

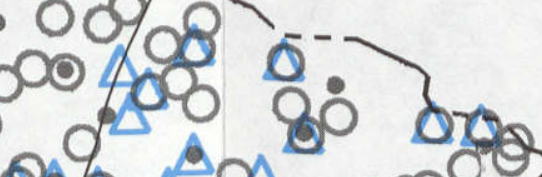

1. $0400^{\circ} 00^{\circ}$ 



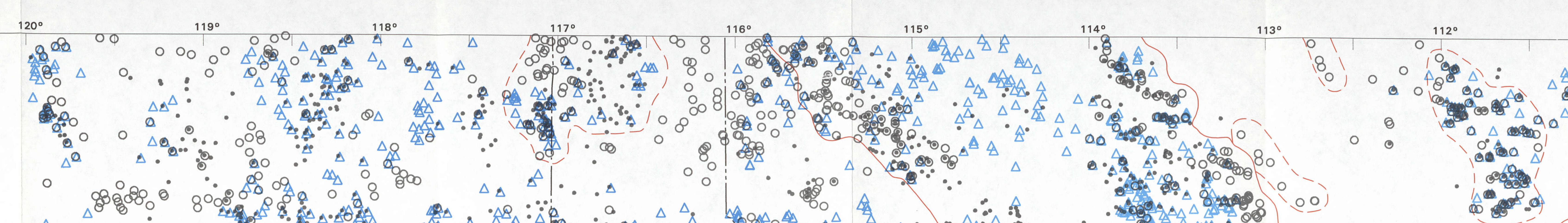

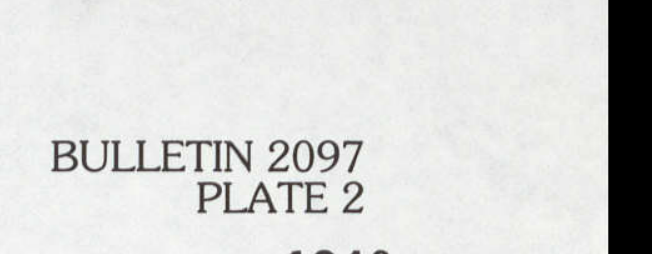

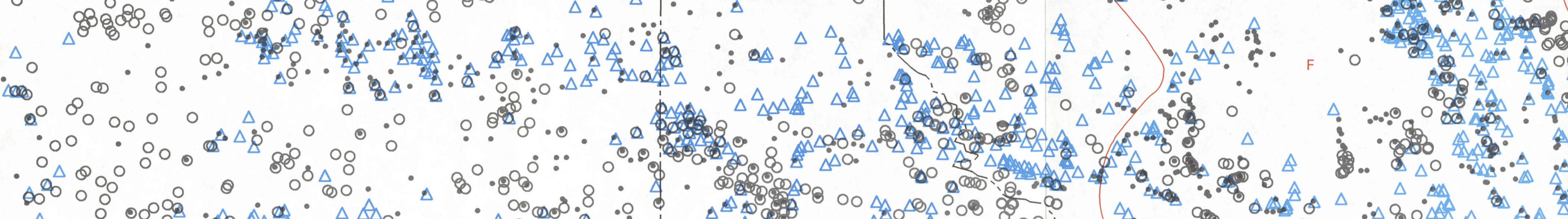

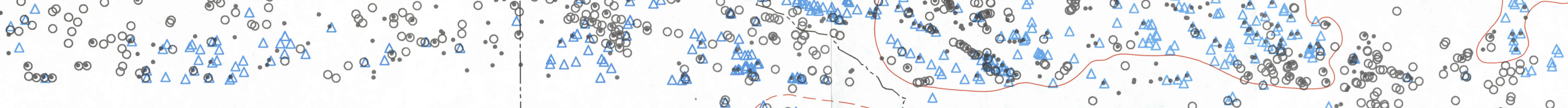
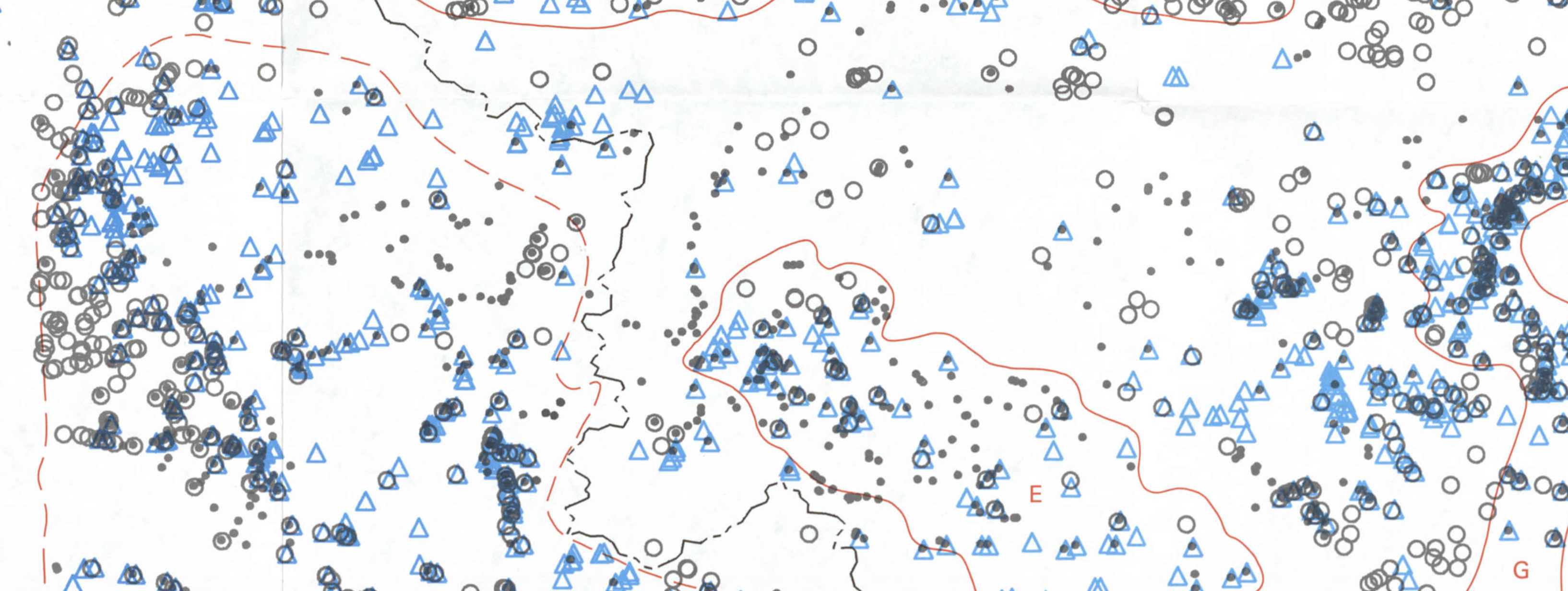

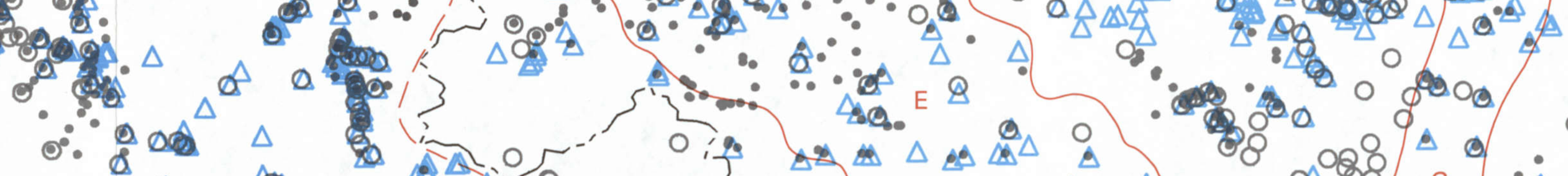
$80^{2}$

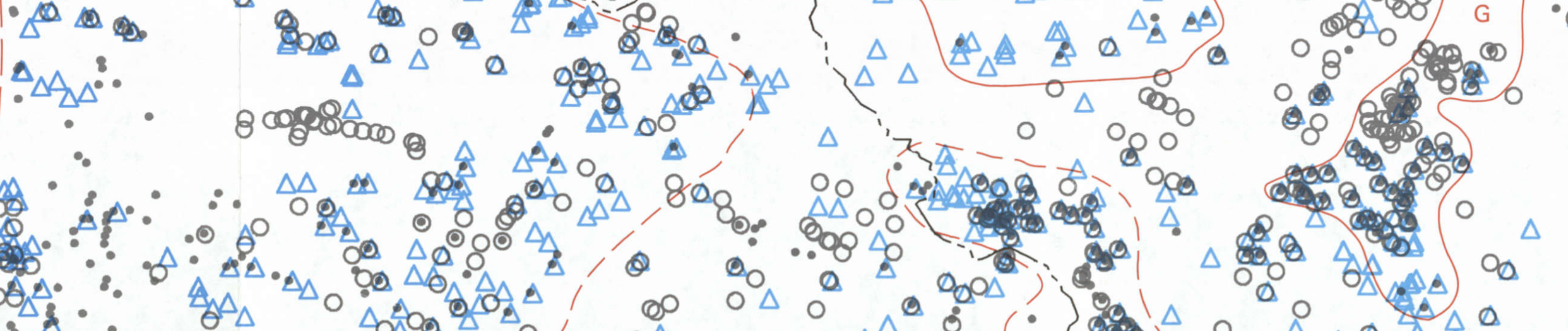

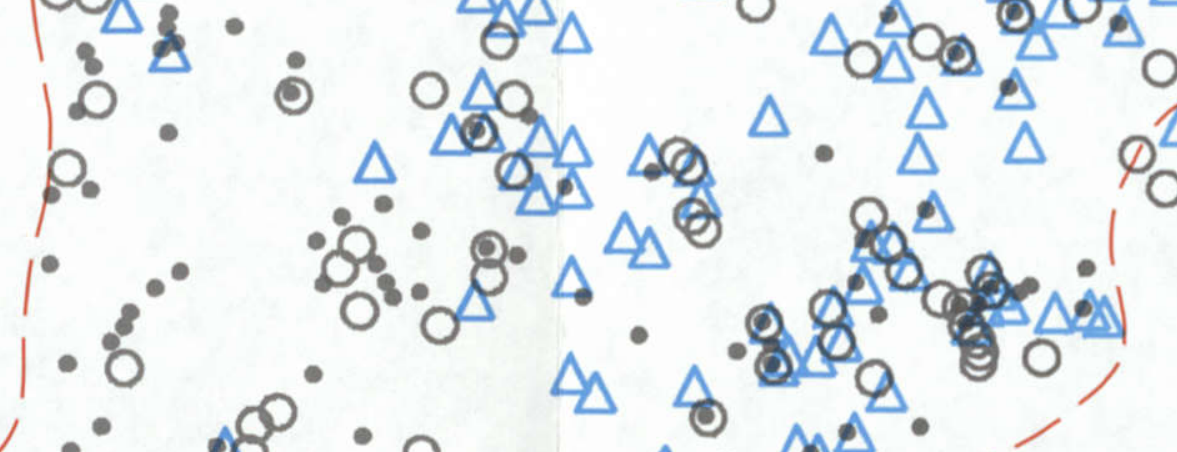

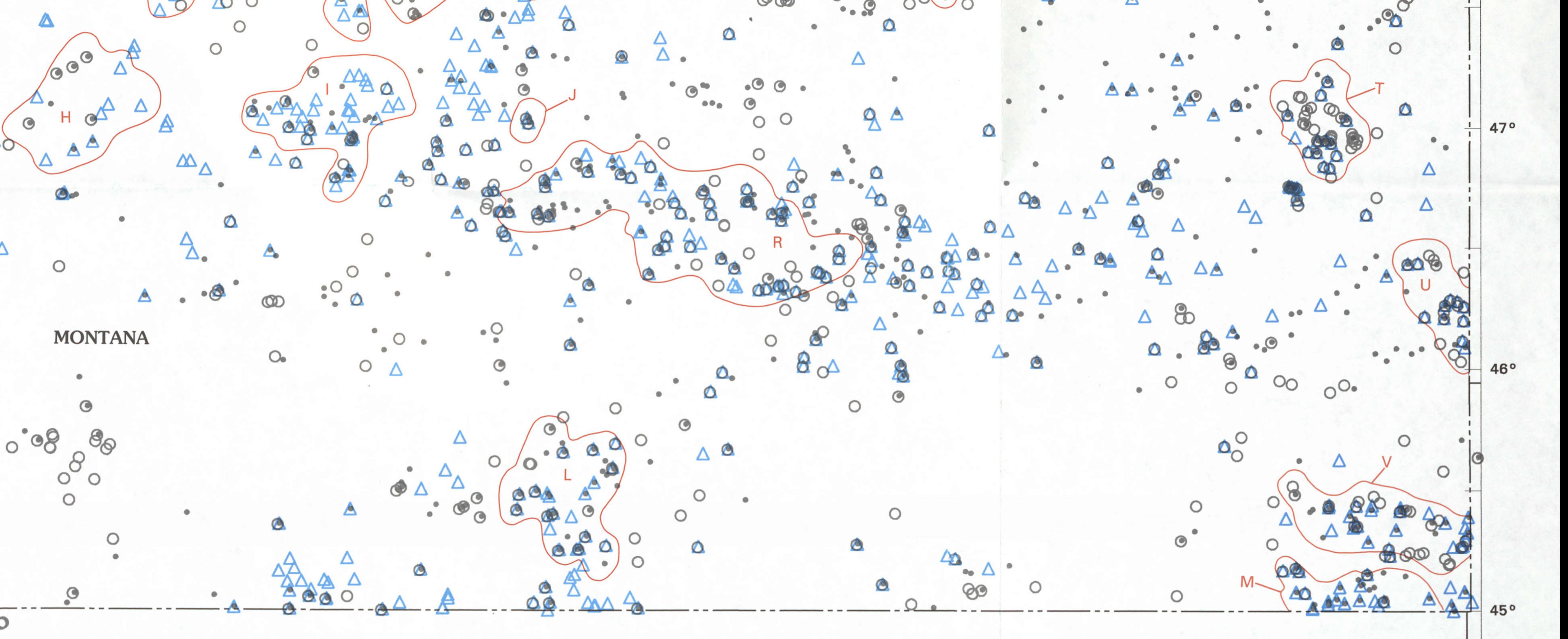


